\title{
Prediction of Mechanical properties of Al Alloy 6061-T6 by using GMAW
}

\author{
Sagar R.Chikhale*\#, Kishor P.Kolhe\& and Pawan Kumar\$ \\ \#Department of Mechanical Engineering, Imperial College of Engineering and Research Wagholi Pune, India \\ \&Department of Mechanical Engineering, JSPM'S Imperial College of Engineering and Research Wagholi Pune, India \\ \$VRDE (DRDO) Ahmednagar, Maharashtra, India
}

Accepted 15 June 2016, Available online 20 June 2016, Special Issue-5 (June 2016)

\begin{abstract}
Aluminum and its alloys are having variety of applications in today's industrial scenario. The use of Al and its alloys are increasing day by day due to its specific properties, like light weight, high strength, and excellent corrosion resistance. Present study is conducted on Aluminum 6061 tempered alloy by using semi automatic MIG welding Machine with current range 10A-420A and voltage range 10V-41V.The studies are carried out by using British Welding specification; nine samples were prepared for toughness studies and tensile strength. The CVN samples were prepared by ASTM-E-23 standard. Also tensile specimens were prepared by using ASTM-E28/E8M-09 for identifying the tensile strength of weld specimen. The testing was carried out by using Universal testing machine with hydraulic grip. However the fracture toughness studies were carried out by using Charpy V-Notch testing machine, Pendulum Impact Tester Model AI - IT 30. The maximum and minimum UTS noted for the welded joint was $196 \mathrm{MPa}$ and $84 \mathrm{MPa}$ for $0.80 \mathrm{KJ} / \mathrm{mm}$ and $0.3 \mathrm{KJ} / \mathrm{mm}$ heat input respectively. However the Maximum and minimum CVN value noted 26 Jules and 8 Jules for $0.80 \mathrm{KJ} / \mathrm{mm}$ and $0.30 \mathrm{KJ} / \mathrm{mm}$ respectively. The maximum failures of large structures were observed from the Heat affected zone of welding. The HAZ can be minimizing by selecting the appropriate welding parameters like current, voltage and speed etc. S/N ratio analysis and ANOVA analysis were carried out for finding the optimal level of process parameters and significant effect of process parameters on Quality characteristics respectively. By considering above the study was undertaken by conducting the experimental work for getting defect free, robust and cost saving weld structures.
\end{abstract}

Keywords: MIG welding, Aluminum Alloy 6061, CVN Test, UTS Test, ANOVA.

\section{Introduction}

Aluminum alloys are alloys in which aluminum is the predominant metal. It covers the typical alloying elements like copper, magnesium, manganese, silicon, tin and zinc. Aluminum alloy plays an important role in engineering and metallurgy field because of fabrication characteristics like formability. Higher strength 6061 alloy finds broad use in welded structural members such as Truck and marine frames, trains, front and rear suspension frames, hydraulic valve bodies, Jigs, fixtures, gears, fasteners and pipelines. The most common temper 6061 aluminium alloy is T6-solution heat treated and artificially aged.

MIG welding has been used widely to join pieces of aluminum alloys in construction of automotive frame, marine frame, and pressure vessels. In the MIG welding process, a gas shield is usually used to protect the arc and the weld from atmospheric contamination, an

*Corresponding author: Sagar R.Chikhale electric potential is established between the electrode and the work piece that needs to be welded, such electric potential will cause the current to flow and consequently a thermal energy will be generated in the partially ionized inert gas. The circuit diagram of GMAW is illustrated in figure 1 . It consist of various parts as 1) welding power source and cables 2) Inert Gas cylinder 3)filler wire and wire feed unit 4) welding gun and cooling water supply. Various Inert gases are used in MIG welding, like Argon, $\mathrm{CO}_{2}$, Argon and $\mathrm{CO}_{2}$ mixtures, argon mixtures with oxygen or helium mixtures.

K. P. Kolhe and C. K. Datta were studied mechanical properties of submerge arc welded specimens for different passes with different heat inputs. The hardness, impact energy and micro hardness of multipass welded joint were tested by using Rockwell hardness testing machine and charpy V- notch testing machine. The proportionate value of micro hardness was observed for low heat input where as for increased heat input variations in hardness value was observed. They concluded welding parameters of SAW used to 
control mechanical properties of welded joint and help to get the robust welded structure of mild steel.

P.A.Stathers, et al. were found relationship between hardness and tensile properties for $\mathrm{HAZ}$ in $\mathrm{Al}$ alloy 6061-T651. They were found that hardness is a sole variable for estimating the yield and tensile strength of the heat affected zone (HAZ) in welding. The relations have been expressed mathematically as follows $0.2 \%$ Yield stress $=2.9263 \mathrm{HV}-44.289 \ldots$ (1) Tensile strength $=2.4079 \mathrm{HV}+46.39 \ldots$ (2) K.S.Bang, et al. were studied HAZ hardness and tensile strength in welds made with different heat inputs in fine-grained ferritic-pearlitic TMCP steel. First they estimated softening zone by micro hardness distribution using Vickers hardness Test, after that the degree of softening was also predicted using an established microstructural evolutional model. They observed that softening zone width increased continuously to 10 $\mathrm{KJ} / \mathrm{mm}$, the minimum hardness in the softened zone decreased slightly after a rapid decrease up to $6 \mathrm{KJ} / \mathrm{mm}$ due to the softening effect, welded join tensile specimens were broken at the HAZ instead of Base metal. The reduction of tensile strength was similar to that of hardness and showed a maximum of $20 \%$ at 6 $\mathrm{KJ} / \mathrm{mm}$. M.Miyazaki, et al. were investigated the influence of the grain size on the weld heat affected zone cracking of Gas metal arc(GMA) welds on AA 6061 was studied using a varestraint test.

The maximum crack length increased when the grain size was increased from 0.005 to $2 \mathrm{~mm}$. They observed the solidus temperature was increased by $\mathrm{Si}$ and decreased by $\mathrm{Mg}$, the maximum crack length was longer in the case of 4043 (silicon based filler metal) than 5356(Magnesium based filler metal). Filler metals may affect the weld chemistry and respective mechanical and thermodynamic properties. S.Y.Marchant investigated the effect of welding current on welding speed and hardness of heat affected zone and weld zone of mild steel material, It was observed that with increase in welding current melting rate of electrode was increased hence welding time was reduced. So welding speed was increased. With increase in welding current hardness of HAZ and weld metal was also decreased due to increase in heat input. A.N.Boob and G.K.Gattani were studied effect of manual arc welding process parameters like heat input and welding speed on width of Heat affected zone for Ms 1005 Steel. It was observed that welding speed increase the width of HAZ decreases and by increasing heat input decreases the toughness. R.R.Ambriz, et al. were investigated Local mechanical properties of a weld zone, in a 6061-T6 aluminum alloy subjected to modified indirect electric arc technique. It showed the intress of the hardness mapping for identifying the different zones resulting from the welding process J.A.Vargas, et al. were studied yield strength and microstructure during welding (GMAW) for different heat inputs. A transient thermal analysis was developed to model the problem in a numerical form using finite element method (FEM) and these results were compared with experimental data showing good agreement. The methodology and results of this work could be used as a tool to optimized welding processes based on the prediction of mechanical properties such as yield strength and micro hardness.A. Hooda, et al were identified the empirical relationship of process parameters to predict the yield strength of inert gas metal arc welded AISI 1040 medium carbon steel. The Process parameters such as welding voltage, current, wire speed and gas flow rate were studied. The experiments were conducted based on a four-factor, three-level, and face centered composite design matrix. Response Surface Methodology (RSM) was applied to optimizing the MIG welding process parameters to attain the maximum yield strength of the joint S.D.Ambekar and S.R.Wadhokar were studied Parametric Optimization of Metal inert gas welding process by using Taguchi method on stainless steel AISI 410.Sixteen experimental runs (L16) based on an orthogonal array Taguchi method were performed. The ANOVA and signal to noise ratio is applied to identify the most significant factor and predicted optimal parameter setting. This paper presents the effect of welding parameters like welding speed, welding current and wire diameter on penetration.

\section{Design of experiment}

Pre-selected weld parameters were selected before to the start of the welding process and they cannot be changed during the welding process. These parameters, variables, include the electrode type, size, the torch nozzle size, and the shielding gas type. The indirect weld parameters of the welding process include the arc voltage, arc current, travel speed, shielding gas and wire feed rate. Indirect weld parameters are parameters that can be modified in process. Once the pre selected variables are properly chosen, the quality of the weld can be controlled through proper selection and modification of the indirect weld parameters. In any welding process, the input parameters have an influence on the weld joint mechanical properties. By varying the input process parameters combination the output would be different welded joints with significant variation in their mechanical properties. The input parameters play a very significant role in determining the quality of a welded joint. Generally most of the researcher uses Taguchi approach for Design of experiment (DOE) because it can significantly reduce time required for experimental investigations but in present investigation the DOE carried out nine experiments as per welding current range from $75 \mathrm{~A}$ to $275 \mathrm{~A}$ having nine levels, welding voltage range from $20 \mathrm{~V}$ to $26 \mathrm{~V}$ having three levels and welding speed constant. Dr. Taguchi's Signal-to-Noise ratios $(\mathrm{S} / \mathrm{N})$, which are log functions of desired output, used as objective functions for optimization, help in data analysis and prediction of optimum results.

\section{Signal to Noise Ratio (S/N):}

The following three types of $\mathrm{S} / \mathrm{N}$ ratio are employed in practice: 
(i) Smaller-The-Better: $\mathrm{S} / \mathrm{N}=-10 \log _{10}$ [mean of sum of squares of measured data]

(ii) Larger-The-Better: $\mathrm{S} / \mathrm{N}=-10 \log _{10}$ [mean of sum squares of reciprocal of measured data]

(iii) Nominal-The-Best: $\mathrm{S} / \mathrm{N}=10 \log _{10}$ [square of mean / variance]

\section{Experimental Procedure}

The experiments were carried out on Semi automatic Metal Inert Gas arc welding machine model PRO-4200 in a single Run which is shown in figure 2. Argon gas with gas flow rate $25 \mathrm{~L} / \mathrm{min}$ used as a shielding gas to protect the arc and weld bed from atmospheric contamination. $1.2 \mathrm{~mm}$ diameter ER 4043 Filler wire used to weld the test specimens. The material chosen for the present study was aluminium alloy 6061-T6. Sample of $150 \times 100 \times 10 \mathrm{~mm}$ size has been used as a work piece material. The chemical Composition results are shown in Tabe-1. The aluminium alloy 6061-T6 Sheet is converted in to nine samples as per desired work piece size by using cutting operation. $60^{\circ} \mathrm{V}$ edge preparation was made on these specimens as shown in figure 3. Set up was made by tack welding. Root gap and root face kept $2 \mathrm{~mm}$ each. Welding process parameters taken as per Table-2. Welding current, Welding Voltage varied and Welding speed, Gun Nozzle tip to plate distance, and gas flow rate remained constant. A specific code were made for each welded specimen in which $M$ assigned for MIG welded specimen, A61 assigned for aluminium alloy 6061-T6 and The number followed by this code indicates Experiment number. Total nine experiments were carried out within the welding current range from $75 \mathrm{~A}$ to $275 \mathrm{~A}$. After welding CVN sample prepared as per ASTM-E-23 standard from the MIG welded specimens shown in figure 4. Toughness test were made using the Charpy impact test machine, Pendulum impact modelAI-13.Tensile samples were prepared as per ASTME8/E8M-09 Standard from the MIG welded specimens which is shown in figure 5 . Tensile test were made using Universal Testing Machine (UTM) with hydraulic grip.

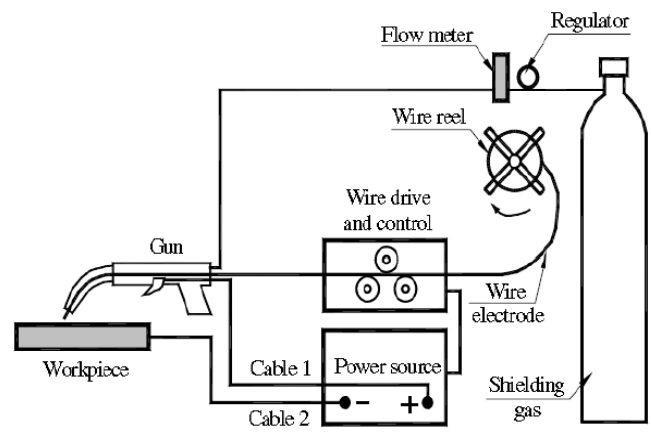

Fig.1 GMAW Machine Setup
Table 1 Chemical Composition of AA6061-T6

\begin{tabular}{|c|c|}
\hline Alloying Element & Weight (\%) \\
\hline $\mathrm{Si}$ & 0.66 \\
\hline $\mathrm{Fe}$ & 0.3 \\
\hline $\mathrm{Cu}$ & 0.27 \\
\hline $\mathrm{Mn}$ & 0.007 \\
\hline $\mathrm{Mg}$ & 1.0 \\
\hline $\mathrm{Cr}$ & 0.18 \\
\hline $\mathrm{Zn}$ & 0.05 \\
\hline $\mathrm{Ti}$ & 0.02 \\
\hline Aluminium & 97.45 \\
\hline
\end{tabular}

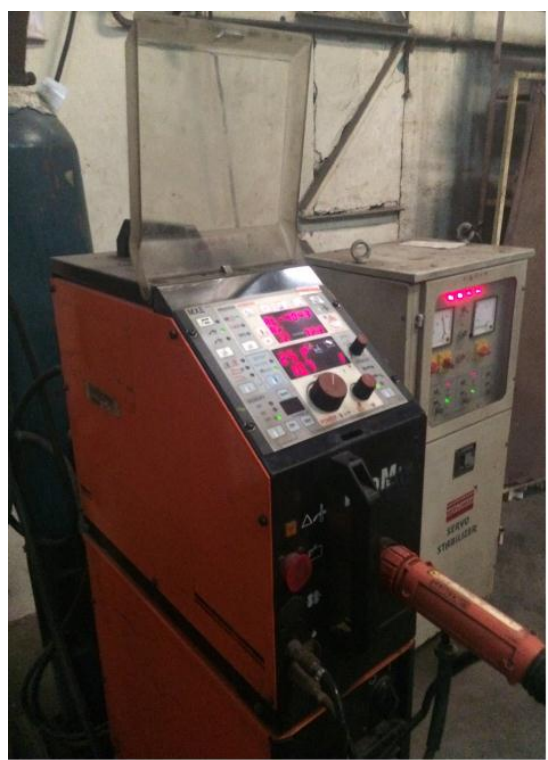

Fig.2 Gas Metal Arc Welding machine
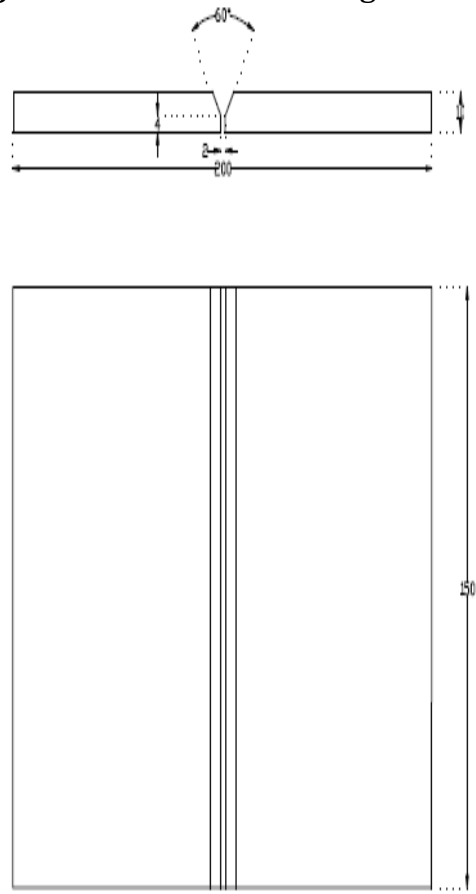

Fig.3 MIG Welding Sample 
Table 2 Welding parameters and their levels

\begin{tabular}{|c|c|c|c|c|}
\hline $\begin{array}{c}\text { Exp } \\
\text { No. }\end{array}$ & $\begin{array}{c}\text { Welding } \\
\text { current (I) } \\
\text { in Ampere }\end{array}$ & $\begin{array}{c}\text { Welding } \\
\text { Voltage } \\
\text { (V) in Volt }\end{array}$ & $\begin{array}{c}\text { Welding } \\
\text { Speed (S) in } \\
\mathrm{mm} / \mathrm{min}\end{array}$ & $\begin{array}{c}\text { Heat Input } \\
\text { in KJ/mm }\end{array}$ \\
\hline 1 & 75 & 20 & 300 & 0.300 \\
\hline 2 & 100 & 20 & 300 & 0.400 \\
\hline 3 & 125 & 20 & 300 & 0.500 \\
\hline 4 & 150 & 23 & 300 & 0.690 \\
\hline 5 & 175 & 23 & 300 & 0.805 \\
\hline 6 & 200 & 23 & 300 & 0.920 \\
\hline 7 & 225 & 26 & 300 & 1.170 \\
\hline 8 & 250 & 26 & 300 & 1.300 \\
\hline 9 & 275 & 26 & 300 & 1.430 \\
\hline
\end{tabular}

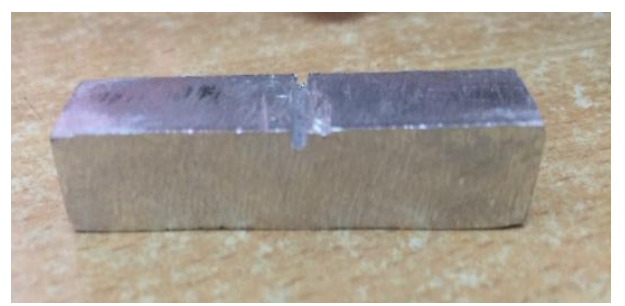

Fig.4 Charpy Impact Test Specimen as per ASTM-E-23

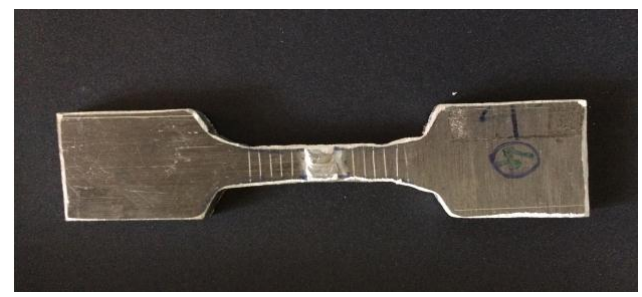

Fig. 5 Tensile Testing Sample as Per ASTM-E8/E8M-09

\section{Analysis of $S / N$ ratio}

In S/N Ratio analysis the term 'Signal' represents the desirable value (mean) for the output quality characteristics like Penetration, Toughness and Tensile strength. The term 'Noise' represents the undesirable value (standard deviation) for the output quality characteristics. Therefore $\mathrm{S} / \mathrm{N}$ Ratio is the ratio of Mean to Standard Deviation and used to measure the quality characteristic deviating from the desired value. Mathematically it is represented as,

$$
\mathrm{S} / \mathrm{N}=-10 \log \text { (M.S.D.) (1) }
$$

Where, M.S.D. is the mean square deviation for the output quality characteristic. For obtaining optimal welding performance, Larger-The-Better quality characteristic for penetration, Toughness and Tensile strength must be taken. The M.S.D. for Larger-TheBetter quality characteristic can be expressed as

$$
\text { M.S.D }=1 / \mathrm{n}\left(\sum 1 / \mathrm{y}^{2}\right)(2)
$$

Where ' $n$ ' is the number of measurements in a trial / row, in this case, $n=1$ and $y$ is the measured value in a run / row. S/N ratio values are calculated by using equation 1 and 2. Experimental results (the output characteristics values) and their corresponding $\mathrm{S} / \mathrm{N}$ ratio values are listed in table 3 . Regardless of the category of the performance characteristics, a greater $\mathrm{S} / \mathrm{N}$ value corresponds to a better performance.
Therefore, the optimal level of the welding parameters is the level with the greatest $\mathrm{S} / \mathrm{N}$ value. The $\mathrm{S} / \mathrm{N}$ Response table Performance characteristics are shown in Table No.4 to 6.

Table 3 Experimental Results for Performance

\begin{tabular}{|c|c|c|c|c|c|c|}
\hline \multirow[b]{2}{*}{$\begin{array}{l}\dot{0} \\
z \\
\text { à } \\
\text { x }\end{array}$} & \multicolumn{6}{|c|}{ Performance characteristics and their $\mathrm{S} / \mathrm{N}$ values. } \\
\hline & 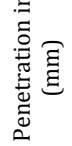 & 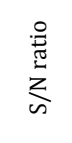 & 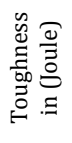 & 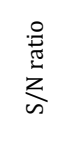 & 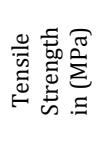 & 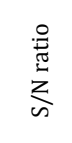 \\
\hline$\frac{\vec{I}}{\dot{b}}$ & 5.0 & 13.98 & 08 & 18.06 & 84 & 38.48 \\
\hline $\begin{array}{l}\stackrel{N}{\dot{\Delta}} \\
\stackrel{\mathbb{L}}{\Sigma}\end{array}$ & 4.0 & 12.04 & 09 & 19.08 & 124 & 41.87 \\
\hline$\frac{m}{\dot{1}}$ & 4.5 & 13.06 & 14 & 22.92 & 127 & 42.07 \\
\hline$\frac{\dot{H}}{\dot{b}}$ & 6.0 & 15.56 & 12 & 21.58 & 152 & 43.63 \\
\hline 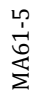 & 7.0 & 16.90 & 26 & 28.30 & 196 & 45.84 \\
\hline 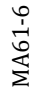 & 6.0 & 15.56 & 14 & 22.92 & 161.6 & 44.17 \\
\hline$\frac{\hat{1}}{\dot{b}}$ & 6.5 & 16.26 & 04 & 12.04 & 176 & 44.91 \\
\hline 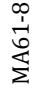 & 4.8 & 13.62 & 10 & 20 & 118.4 & 41.46 \\
\hline$\frac{a}{\dot{1}}$ & 3.0 & 9.54 & 10 & 20 & 122.4 & 41.75 \\
\hline
\end{tabular}
characteristics and $\mathrm{S} / \mathrm{N}$ ratio

\begin{tabular}{|c|c|c|c|c|c|c|c|c|c|}
\hline \multirow{2}{*}{ 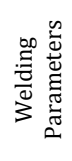 } & \multicolumn{9}{|c|}{ Mean S/N Ratio of Welding parameter levels } \\
\hline & 1 & 2 & 3 & 4 & $\mathbf{5}$ & 6 & 7 & 8 & 9 \\
\hline $\begin{array}{l}\stackrel{\vec{v}}{\vec{v}} \\
\vec{\Xi}\end{array}$ & $\begin{array}{l}\infty \\
\stackrel{\infty}{ } \\
\dot{m} \\
\end{array}$ & 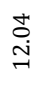 & 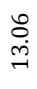 & $\begin{array}{l}\text { 号 } \\
\text { ஸी }\end{array}$ & $\begin{array}{l}\text { هి } \\
\text { ف에 }\end{array}$ & $\begin{array}{l}\text { ํํ } \\
\text { L్ }\end{array}$ & $\begin{array}{l}\stackrel{\sim}{0} \\
\underset{\sim}{0}\end{array}$ & $\begin{array}{l}\tilde{\sigma} \\
\stackrel{\sim}{\rightarrow}\end{array}$ & 9.5 \\
\hline $\begin{array}{l}\text { 品 } \\
\text { 苛 } \\
\end{array}$ & $\begin{array}{l}\tilde{O} \\
\stackrel{\text { m}}{\sim}\end{array}$ & $\stackrel{\sim}{\sim}$ & $\underset{\vec{m}}{\vec{m}}$ & ' & 1 & ' & ' & ' & - \\
\hline 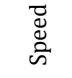 & 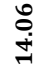 & ' & ' & ' & ' & ' & ' & ' & - \\
\hline
\end{tabular}

Table $4 \mathrm{~S} / \mathrm{N}$ response table for Penetration 
Table $5 \mathrm{~S} / \mathrm{N}$ response table for Toughness

\begin{tabular}{|c|c|c|c|c|c|c|c|c|c|}
\hline \multirow{2}{*}{ 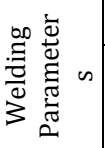 } & \multicolumn{9}{|c|}{ Mean S/N Ratio of Welding parameter levels } \\
\hline & $\rightarrow$ & $N$ & $m$ & + & 10 & 0 & $\wedge$ & $\infty$ & $a$ \\
\hline $\begin{array}{l}\stackrel{\overrightarrow{0}}{0} \\
\stackrel{\Xi}{\Xi}\end{array}$ & $\begin{array}{l}0 \\
0 \\
\infty \\
\rightarrow\end{array}$ & $\begin{array}{l}\infty \\
\stackrel{0}{\circ} \\
\stackrel{-}{-}\end{array}$ & $\begin{array}{l}\underset{N}{N} \\
\underset{N}{n}\end{array}$ & 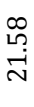 & $\begin{array}{l}\text { @ి } \\
\text { 心) } \\
\text { N }\end{array}$ & 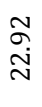 & $\underset{\sim}{\underset{J}{J}}$ & ิ & $\stackrel{\curvearrowright}{N}$ \\
\hline 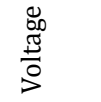 & $\begin{array}{l}\text { ô. } \\
\stackrel{\text { N }}{ }\end{array}$ & $\begin{array}{l}\stackrel{0}{N} \\
\stackrel{N}{N}\end{array}$ & 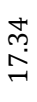 & ' & ' & ' & ' & ' & ' \\
\hline $\begin{array}{l}\text { d } \\
\mathbb{D} \\
\text { के }\end{array}$ & $\begin{array}{l}\text { Ln } \\
\text { مึ } \\
\text { ำ }\end{array}$ & & ' & ' & ' & & ' & & ' \\
\hline
\end{tabular}

Table $6 \mathrm{~S} / \mathrm{N}$ response table for Tensile strength

\begin{tabular}{|c|c|c|c|c|c|c|c|c|c|}
\hline \multirow{2}{*}{ 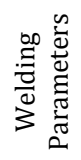 } & \multicolumn{9}{|c|}{ Mean S/N Ratio of Welding parameter levels } \\
\hline & -1 & $N$ & $m$ & $\vec{\sigma}$ & L & 6 & r & $\infty$ & $\sigma$ \\
\hline $\begin{array}{l}\stackrel{\overrightarrow{0}}{0} \\
\stackrel{\Xi}{\Xi}\end{array}$ & 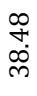 & $\begin{array}{c}\hat{\infty} \\
\overrightarrow{+}\end{array}$ & $\begin{array}{l}\hat{O} \\
\stackrel{\text { H }}{\text { t }}\end{array}$ & $\begin{array}{l}\tilde{\sigma} \\
\stackrel{\tilde{F}}{ }\end{array}$ & 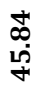 & Fे & $\begin{array}{l}\bar{\sigma} \\
\dot{+}\end{array}$ & 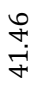 & \\
\hline $\begin{array}{l}0 \\
\frac{\pi}{\pi} \\
\frac{\pi}{0}\end{array}$ & $\begin{array}{l}\infty \\
\infty \\
\dot{+} \\
\dot{+}\end{array}$ & 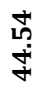 & $\begin{array}{l}\stackrel{ }{\text { Hิ }} \\
\text { }\end{array}$ & ' & ' & ' & & ' & ' \\
\hline 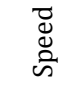 & 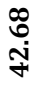 & ' & ' & ' & ' & ' & & ' & ' \\
\hline
\end{tabular}

\section{AVOVA (Analysis of Variance)}

The purpose of the analysis of variance (ANOVA) is to investigate which design parameters significantly affect the quality characteristic. ANOVA help in formally testing the significance of all main factors and their interactions by comparing the mean square against an estimate of the experimental errors at specific confidence levels. The sum of square (SS), the degrees of freedom (D), the variance (V) and the percentage of contribution to the total variation (P) are used in ANOVA; Results are illustrated in Table No.7 to Table No.9.

Table 7 Results of ANOVA for Penetration

\begin{tabular}{|c|c|c|c|c|c|}
\hline 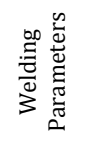 & 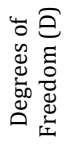 & 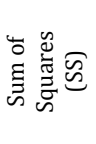 & 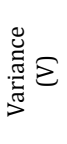 & 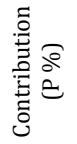 & 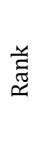 \\
\hline Current & 8 & 26.60 & 3.32 & 61.70 & 1 \\
\hline Voltage & 2 & 15.95 & 7.97 & 36.99 & 2 \\
\hline Speed & 0 & 0.56 & 0.56 & 1.30 & 3 \\
\hline Total & 10 & 43.11 & & 100 & \\
\hline
\end{tabular}

Table 8 Results of ANOVA for Toughness

\begin{tabular}{|c|c|c|c|c|c|}
\hline 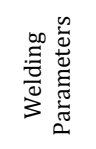 & 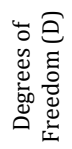 & 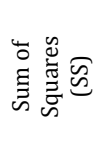 & 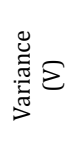 & 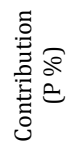 & 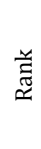 \\
\hline Current & 8 & 80.28 & 10.03 & 52.22 & 1 \\
\hline Voltage & 2 & 71.40 & 35.7 & 46.44 & 2 \\
\hline Speed & 0 & 2.06 & 2.06 & 1.34 & 3 \\
\hline Total & 10 & 153.74 & & 100 & \\
\hline
\end{tabular}

Table 9 Results of ANOVA for Tensile Strength

\begin{tabular}{|c|c|c|c|c|c|}
\hline 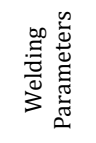 & 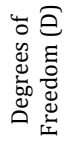 & 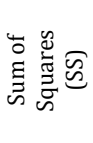 & 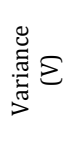 & 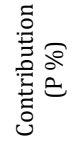 & 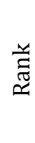 \\
\hline Current & 8 & 28.36 & 3.54 & 72.53 & 1 \\
\hline Voltage & 2 & 15.86 & 7.93 & 40.56 & 2 \\
\hline Speed & 0 & -5.12 & -5.12 & -13.09 & 3 \\
\hline Total & 10 & 39.10 & & 100 & \\
\hline
\end{tabular}

\section{Confirmation Test}

In order to validate the methodology, a confirmation test was performed by setting the optimum conditions for three welding parameters are illustrated in Table No.10.The predicted S/N ratio can be calculated using this combination of parameters with the following equation.

$[\mathrm{S} / \mathrm{N}]_{\text {Predicted }}=[\mathrm{S} / \mathrm{N}]_{\text {Mean }}+\sum_{\mathrm{i}=1}\left([\mathrm{~S} / \mathrm{N}]_{\mathrm{i}}-[\mathrm{S} / \mathrm{N}]_{\mathrm{m}}\right)$

Where $[\mathrm{S} / \mathrm{N}]_{\mathrm{m}}$ is the total $\mathrm{S} / \mathrm{N}$ ratio, $[\mathrm{S} / \mathrm{N}]_{\mathrm{i}}$ is the mean $\mathrm{S} / \mathrm{N}$ ratio at the optimal level, and $\mathrm{y}$ is the number of main design parameters that affect the quality characteristic. Table 11, 12 and 13 shows good agreement between the predicted and the experimental depth of penetration, Toughness and Tensile strength respectively. The optimum combination of process parameters is almost matching with the parameters used for producing track 5 in the present study.

Table 10 Optimum process parameters for quality characteristics

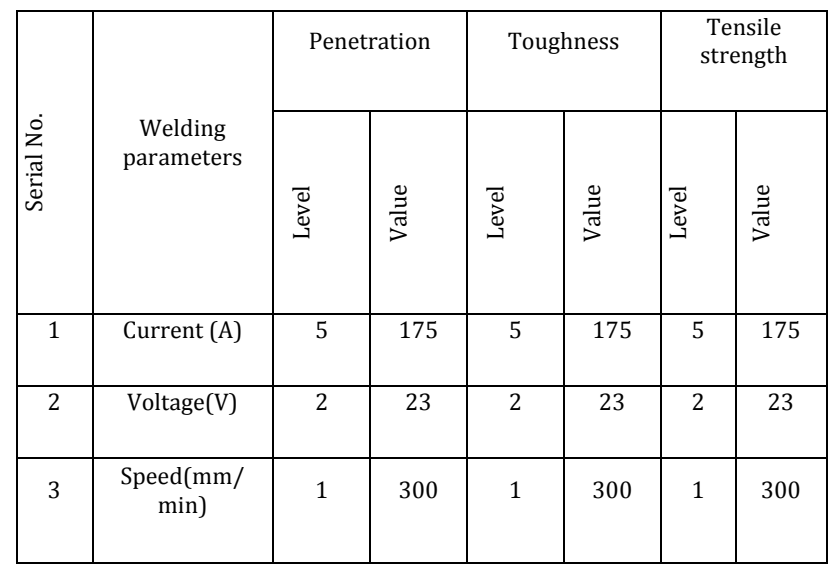


Table 11 Confirmation Testing for Penetration to validate the approach

\begin{tabular}{|c|c|c|c|c|c|c|c|}
\hline & \multicolumn{3}{|c|}{ Parameters } & \multicolumn{2}{|c|}{$\mathrm{S} / \mathrm{N}$ ratio } & \multicolumn{2}{|c|}{$\begin{array}{l}\text { Performance } \\
\text { values for } \\
\text { penetration } \\
(\mathrm{mm})\end{array}$} \\
\hline & $\stackrel{\overrightarrow{0}}{\stackrel{\overrightarrow{0}}{\Xi}}$ & 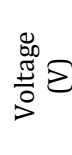 & 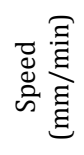 & 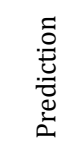 & 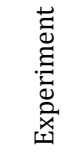 & 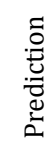 & 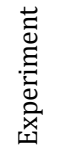 \\
\hline 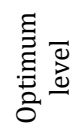 & 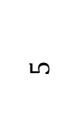 & $N$ & -1 & \multirow{2}{*}{18.84} & \multirow{2}{*}{16.90} & \multirow{2}{*}{7.9} & \multirow{2}{*}{7.0} \\
\hline 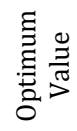 & $\stackrel{\llcorner}{\stackrel{\llcorner}{二}}$ & $\stackrel{?}{N}$ & m & & & & \\
\hline
\end{tabular}

Table 12 Confirmation Testing for Toughness to validate the approach.

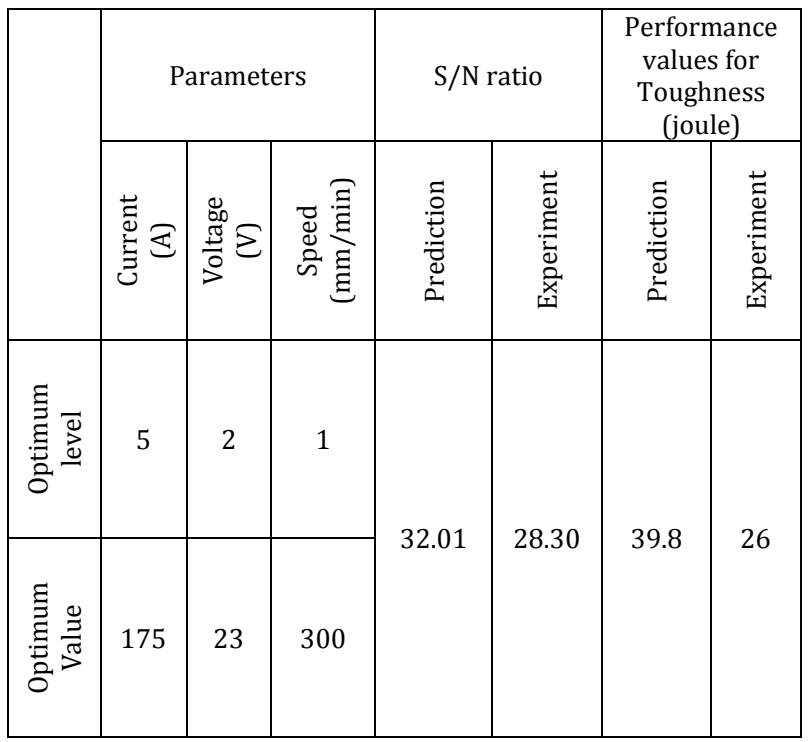

Table 13 Confirmation Testing for Tensile strength to validate the approach

\begin{tabular}{|c|c|c|c|c|c|c|c|}
\hline & & ameter & & & atio & $\begin{array}{r}\text { Perfo } \\
\text { valu } \\
\text { Te } \\
\text { stre } \\
\text { ( }\end{array}$ & $\begin{array}{l}\text { ance } \\
\text { cor } \\
\text { e } \\
\text { th } \\
\text { ) }\end{array}$ \\
\hline & $\stackrel{\overrightarrow{0}}{\stackrel{\Xi}{\Xi}}$ & 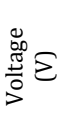 & 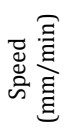 & 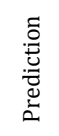 & 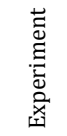 & 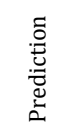 & 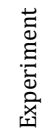 \\
\hline $\begin{array}{l}\text { Optimum } \\
\text { level }\end{array}$ & 5 & 2 & 1 & 47.7 & 45.84 & 223.8 & 196 \\
\hline $\begin{array}{l}\text { Optimum } \\
\text { Value }\end{array}$ & 175 & 23 & 300 & & & & \\
\hline
\end{tabular}

\section{Result and Discussion}

From the available results of Quality characteristics the direct effect of Heat Input on the Depth of Penetration, Toughness of weld joint and ultimate tensile strength of the weld joint was studied and plotted as shown in Figure 6, 7 and 8.

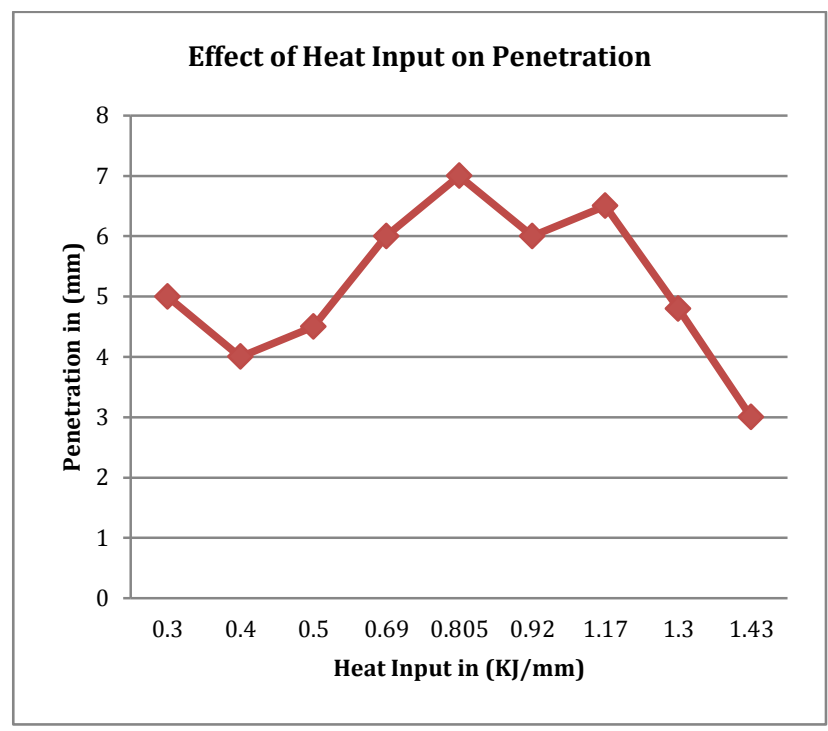

Fig. 6 Relation between Heat Input and Depth of Penetration

Figure 6 depicts the direct effect of Heat Input on Depth of Penetration. From the figure it is observed that the value of Penetration increases as Heat Input increases till $0.805 \mathrm{KJ} / \mathrm{mm}$. after that value of penetration decreases against the increment in Heat input. The maximum penetration $7 \mathrm{~mm}$ observed at $0.805 \mathrm{KJ} / \mathrm{mm}$ of heat input and minimum penetration 3 $\mathrm{mm}$ observed at the peak value of Heat input $1.43 \mathrm{KJ} / \mathrm{mm}$

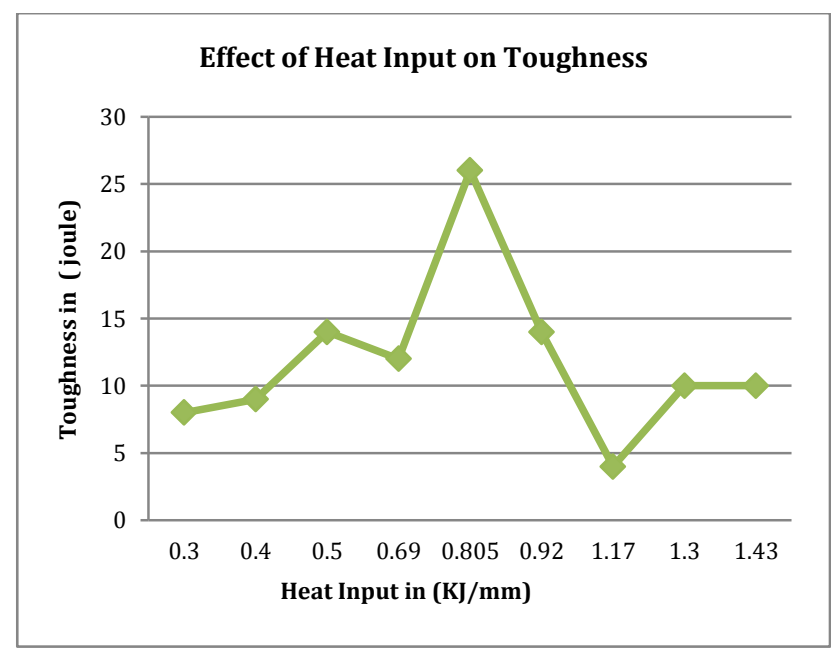

Fig. 7 Relation between Heat Input and Toughness of weld joint

Figure 7 depicts the direct effect of Heat Input on Toughness of weld joint. From the figure it is observed 
that the value of Toughness increases till $0.805 \mathrm{KJ} / \mathrm{mm}$. after that value of Toughness decreases till $1.17 \mathrm{KJ} / \mathrm{mm}$ and sudden increment in toughness at heat input $1.3 \mathrm{KJ} / \mathrm{mm}$ after that constant value of toughness observed. The maximum toughness 26 joule observed at $0.805 \mathrm{KJ} / \mathrm{mm}$ of heat input and minimum toughness observed at $1.17 \mathrm{KJ} / \mathrm{mm}$ of heat input.

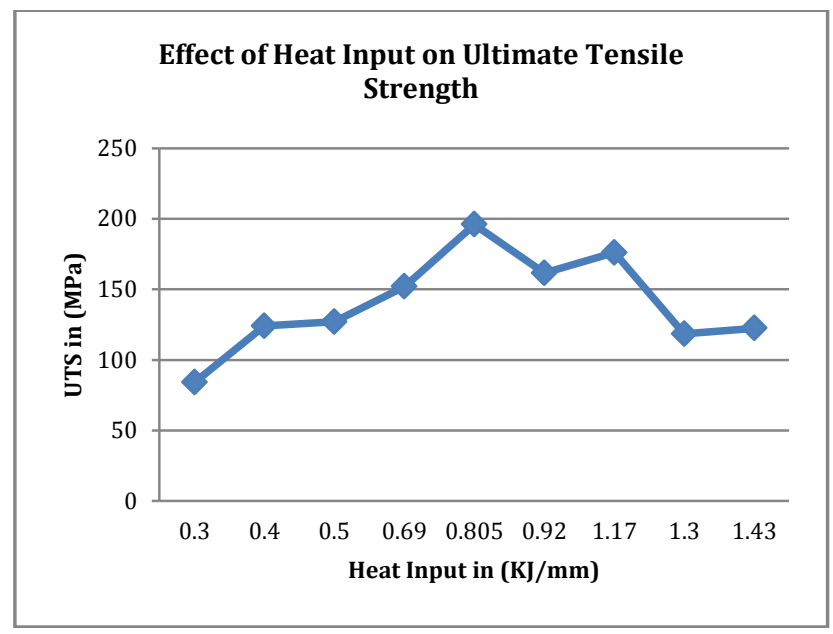

Fig.8 Relation between Heat Input and Ultimate tensile strength of weld joint

Figure 8 depicts the direct effect of Heat Input on Ultimate tensile strength of weld joint. From figure it is observed that the value of UTS increases as heat input increases till $0.805 \mathrm{KJ} / \mathrm{mm}$. after that value of UTS decreases as heat input increases. The maximum value of UTS $196 \mathrm{MPa}$ observed at heat input $0.805 \mathrm{KJ} / \mathrm{mm}$ and minimum value of UTS $84 \mathrm{MPa}$ observed at heat input $0.3 \mathrm{KJ} / \mathrm{mm}$.

\section{Conclusions}

The following conclusions were arrived at based on the present investigations.

1) Taguchi optimization method was applied to find optimal process parameters for penetration, Toughness and Tensile strength of weld joint. Signal to noise ratio(S/N) analysis and analysis of variance (ANOVA) were used for the optimization of welding parameters.

2) The welding current has the most significant influence on the Tensile strength of weld joint, depth of penetration and toughness. Welding Voltage is second most significant factor. The effect of welding Speed is very small in comparison.

3) The percentage of contribution of the welding current is $72.53 \%$ for Tensile strength, $61.70 \%$ for depth of penetration and $52.22 \%$ for Toughness. The percentage of contribution of the welding voltage is $46.44 \%$ for Toughness, $36.99 \%$ for tensile strength, $40.56 \%$ for penetration.
4) The confirmation test demonstrated good agreement between the predicted and the experimental values of quality characteristics.

5) The optimized welding parameters are obtained at a welding current $175 \mathrm{~A}$, welding voltage $23 \mathrm{~V}$, and welding speed $300 \mathrm{~mm} / \mathrm{min}$.

6) The common thing is observed during all the tests that maximum values of quality characteristics observed at heat input $0.805 \mathrm{KJ} / \mathrm{mm}$.

\section{References}

K. P. Kolhe and C.K.Datta [2008], Prediction of microstructure and mechanical properties of multipass saw, Journal of Materials Processing Technology (JMPT), Vol.197, pp.241-249.

P.A. Stathers, A.K. Hellier, R.P. Harrison, M.I. Ripley, and J. Norrish [2014], Hardness-Tensile Property Relationships for HAZ in 6061-T651 Aluminum, Welding Journal, Vol.93, pp.301-311.

K.S. Bang and W.Y.Kim [2002], Estimation and prediction of HAZ Softening in thermo mechanically controlled-Rolled and Accelerated Cooled Steel, Welding Journal, Vol.8, pp.174-179.

M. Miyazaki, K. Nishio, M. Katoh, S.Mukae, and H.W.Kerr [1990], Quantitative Investigation of Heat- Affected Zone Cracking in Aluminum Alloy A6061, Welding Journal, Vol.9, pp.362-371.

S.Y. Merchant [2015], Investigation on effect of welding current on welding speed \& Hardness of HAZ \& weld metal of mild steel, International Journal of Research in Engineering \& Technology, Vol.04, Issue.03, pp.44-48.

A.N.Boob and G.K.Gattani [2013], Study on Effect of Manual metal arc welding process parameters on width of heat affected zone (HAZ) for Ms 1005 Steel, Internationl Journal of Modern Engineering Research,Vol.3,Issue.3,pp.1493-1500.

R.R.Ambriz, D.Chicot, N.Benseddiq, G.Mesmacque, S.D.de la Torre [2011], Local mechanical properties of the 6061-T6 aluminum weld using micro-traction and instrumented indentation European Journal of Mechanics A/Solids, Vol.30, pp.307-315.

J. A. Vargas, Jaime E.Torres, Jovanny A.Pacheco, Roque J.Hernandez [2013], Analysis of heat input effect on the mechanical properties of Al-6061-T6 alloy weld joints: Materials \& Design, Vol. 52, pp.556-564.

A.Hooda, Ashwini Dhingra \& Satpal Sharma [2012], Optimization of Mig Welding Process Parameters to predict maximum yieldstrength in AISi1040, International Journal of Mechanical Engineering and Robotics Research, Vol.1, No.3, pp.203-213.

S.D.Ambekar \& Sunil R.Wadhokar[2015], Parametric optimization of Gas metal arc welding process by using Taguchi method on stainless steel AISI 410,International Journal of Research in Modern Engineering and Emerging Technology,Vol.3,Issue.1,pp.1-9

BOC limited a member of the Linde group [2013], Mig Welding introduction, information broacher, and pp.1-5.

Manikandan M,Nageswara Rao M, Raman jam R, Devendranath Ramkumar,Arivazhagan N \& Reddy G.M[2014], Optimization of the Pulsed Current Gas Tungsten Arc Welding Process Parameters for alloy C-276 using the Taguchi Method, Procedia Engineering, No 97,pp.767-774.

Pawan Kumar, Kolhe K.P. and C K Datta[2009], Optimization of bead geometry of pulsed GTAW process for Aluminum alloy 7039 using Ar+ He gas mixtures, Indian Welding Journal,Vol.42 (4),pp.26-33.

Pawan Kumar Kolhe K. P, and C. K. Datta[2010], Optimization of weld bead geometry for pulsed GTA Welding of Aluminum Alloy 6061 BY TAGUCHI METHOD International Journal of manufacturing Technology and Industrial Engineering,Vol 1(1),pp.39-44. 